can be considered a record of itself on the magnetograph curves." WILliaM ELLIS.

Greenwich, November 9.

[With regard to the case cited by Mr. Ellis, it is worth remark that at the time of Trouvelot's observation, the writer of our "Astronomical Notes" asked Mr. Whipple whether the eruption was accompanied by any anomalous magnetic movements. Mr. Whipple replied: "There was not the slightest magnetic disturbance on June I7, I89I, at the hour you mention, or for days before or since." The point was again raised at the beginning of last year, and to make assurance doubly sure, Mr. Whipple again referred to the Kew curves, but failed to find any trace of what could be termed a magnetic disturbance at the hour in question. (See NATURE, February 25, 1892.)ED.]

\section{THE NEW BIRD-PROTECTION BILL.}

CENTIMENT is a beautiful thing in its way, and $D$ when that way happens to coincide with the way of common sense, the man must be a brute who defies it. But unluckily that does not always happen, as is testified by several instances that could but here shall not be cited, for they will come uncalled to the recollection of many of our readers, and indeed to some they are ever present. These need not to have the difference between a sound and an unsound sentiment pointed out. But there is also a sentiment that is perfectly sound at the start, and yet, chiefly through want of knowledge-we hesitate to call it ignorance, because that might imply blame--sooner or later begins to betray symptoms of running on the wrong track, when, if the brakes cannot be applied, it comes into violent collision with common sense. As the latter is the weightier mass the harm it gets from the impact is not often very serious, and the injuries received seldom cause more than delay, however annoying that may be; but the effect on the lighter body is apt to be destructive, and though in some cases it may be only repelled with stight damage, in others it may be shattered. In either event, seeing that it set out with good intentions, the result is to be regretted.

Of this kind of sentiment is that which actuates the extreme advocates of Bird Protection. Time was when the sickening slaughter of sea-fowl at their breedingstations around our coast appealed alike to sentiment and to common sense--to say nothing of science-to interfere. First carried on for what was called "sport," but soon for the sake of mere lucre, the feathered denizens of our cliffs and beaches were shot down by the thousand, to do nobody any good but the "plume-trader." The Act of Parliament which received the Royal Assent in June I $\$ 69$, and is always to be remembered in connection with the name of Mr. Christopher Sykes, was just in time to save from extinction the population of many a thronged resort which has always presented, and we trust always will present, a spectacle of delight to the large and increasing class of our fellow-countrymen who appreciate the harmonies of nature, even if the resorts on the English coast cannot compare with those

$$
\begin{aligned}
& \text { where the Northern Ocean in vast whirls } \\
& \text { Boils round the naked melancholy isles } \\
& \text { Of sea-girt Thule, or the Atlantic surge } \\
& \text { Pours in among the stormy Hebrides. }
\end{aligned}
$$

That Act may have had its shortcomings : few Acts are witbout them; but nobody can doubt it was effective to do good, and it was followed by other Acts, based on the same principle, and tending to relieve persecuted beings from persecution. An exception indeed must be made as regards one of them, but that one (which was commented upon at the time in these columns ${ }^{1}$ ) only serves to support the allegation in our introductory paragraph. In 1872 some enthusiasts followed the line of sentiment regardless of common sense, and succeeded in converting a well-considered and practical measure into one that

Nก. 1255, voL. 49] was specious and useless. They had their reward, for in the next session their parliamentary leader obtained a Select Committee of the House of Commons to enquire into the subject, and the result of the investigation showed every reasonable person the baselessness of the points for which the extreme party had contended, while three years later the very Bill which they had mutilated and mauled passed through Parliament almost exactly in the form in which it had been originally introduced. The enthusiasts, however, had the satisfaction of stopping useful and much wanted legislation for four years in order to gratify their own gushing and unintelligent sentiment, while their Act, always a dead letter, was superseded by the Act of 1880 which consolidated all previous legislation. Still the spirit that moved the enthusiasts is not dead. In one way or another it shows itself every year - sometimes, though not often, it confines itself within the bounds of common sense, but of late it has become we may say rampant. None of the former Acts had done anything to stay the taking of birds' eggs. Indeed, birds' eggs had been, and that purposely, wholly left out of consideration, and this in the eyes of many excellent people has seemed to be a glaring defect-even a crime. Let us stop birdsnesting, say they, and the number of our birds will be indefinitely increased. Nightingales will multiply, Goldfinches will be as plentiful as Sparrows, and Skylarks will swarm. Little do these good people realise the state of things. Let us grant that in the immediate neighbourhood of towns and large villages, where birds are already at a disadvantage, boys will emerge, and successively rob nest after nest as it is built with an effect that may be called devastating. The case, however, is very different in the country at large. There the first species of those we have just named already enjoys a protection incidentally yet almost invariably conferred upon it by the law of trespass. We can believe almost any act of folly or stupidity on the part of some gamekeepers, and the widely-told story that one of that profession once declared that he destroyed Nightingales because their singing disturbed the nights' rest of his pheasants may have some foundation; but nearlyall observers who have informed themselves by experience will agree that the part of England which Nightingales choose to occupy is generally as fully stocked with them as the place will hold. It is certain to those who watch that the number of Nightingales which return to this country with each returning spring is greater than that which can find room. Hence those ever-recurring contests of melody that we hear from rival cock birds on their first coming, to say nothing of the actual conflicts, often ending in the death of one of the combatants, that take place between the competitors. And it is only natural that it should be so. That if a Nightingale's nest be taken the same birds immediately build a second, and if need be a third, is a perfectly well-known fact, and it would be a very unlucky pair of Nightingales to have their nest robbed thrice in a season. At a very moderate computation the number of young Nightingales that must annually attain their full growth in this country doubles that of their parents, since from five to six are commonly reared in each nest; and, with a large allowance for casualties in youth, it is safe to calculate upon four of each brood having reached maturity when the time of emigration arrives. What happens during their absence from this country is of course beyond our ken, but the certainty with which migratory birds return to their home is now well-recognised; and it is not iess certain that of this species more return to England in spring than are able to find accommodation in our woods. coppices, and shrubberies, as the conflicts just mentioned testify. Hence it would follow that were the taking of a Nightingale's egg made a capital offence, we should not have, one year with another, more Nightingales, though, to retain the number we have, it is impera- 
tive that the old birds should have protection at the breeding season.

To take the second case we have cited, that of the Goldfinch, the details are not the same, though the final result be so. Until some fifteen or twenty years ago the diminution in the numbers of this species was notorious ; but the reasons of that diminution are easily revealed to any enquirer, though it may be hard to say which of them be the stronger. The practice of netting in spring time, now illegal though probably still used in some places, was carried on to an extent that if it were not supported by the clearest evidence people would hardly believe. Combined with this disastrous practice was the fact that so much heath and common land had been brought under the plough, and the mode of agricul ture so much improved, as sensibly to affect the Goldfinch's supply of food, for its fare was truthfully termed by the poet "the thistle's downy seed," combined however with that of other weeds hated by good farmers. But no doubt, at the hands of the bird-catchers, the Goldfinch, being so great a favourite for the cage, still suffers severely, and it may be true that enough do not leave this country at close of summer to satisfy the waste of life that occurs during its migration and in its winter-quarters; though as to any considerable diminution in its numbers being caused by birdsnesting, the notion of such a thing will be scouted by all who have had opportunities of observing its breeding-habits. Our third instance, the Skylark, is without doubt one of those birds that needs protection least. Nobody persecutes him so soon as he ceases to flock and settles with his mate in their chosen spot. Their nest in the growing corn, or the wide pasture, is safe from even the predatory rat, and the open country they haunt is no place for the Sparrow-hawk, that deadly foe to so many small birds. There, in the course of the season, they make their three or four nests, and rear in each as many young, so that the annual increase of the species may be safely computed as five-fold, and when we also consider that thousands if not tens of thousands arrive every autumn on our shores and spread over the whole country, with a safe conscience the most devoted lover of birds may, if he has a mind to it, eat larkpudding in winter without compunction.

We have cited these three cases - the Skylark, the Goldfinch, and the Nightingale, because we have them so frequently put forward by sentimentalists as birds that all right-minded people would wish to see more numerous. We should like to count ourselves among the right-minded, but the sentimentalists must forgive us for refusing to believe that the number can be increased in the way they advocate-visiting with punishment the schoolboys who would take the nests of any one of them. Far otherwise, however, is it with many birds of which the enthusiasts never think. Those, for instance, that habitually breed in places open to all comers, and especially on islands near our coast, on the sea shore, and by the side of inland but navigable waters. In such places there is no law of trespass; and, as all who have been at the pains to inform themselves know, these birds suffer from the way their exposed nests are ravaged, and are surely decreasing in number. Yet by the general public they are little heeded, chiefly because the general public knows nothing about them-not even their names-and moreover encourages the ravages by blindly buying the booty of the ravagers. Thus it is that many a beach, and many a heath, and many a marsh and mere, is made desolate, for the ravage is continued throughout the whole of the breeding-season, with the result that scarcely an egg is left from which a young bird-be it Duck or Gull, Tern or Plover can be hatched. Yet it is obvious that it would not be so very difficult to stop this clestruction, and that witbout interfering with the long-established practice, which we hold to be no more detrimental to their species than it is illegitimate, of taking toll of their

$$
\text { NO. I } 255 \text {, VOL. 49] }
$$

eggs. Pick out the places at which the practice is carried on, and limit the time during which the eggs may there be lawfully gathered, so as to give each pair of birds the opportunity of bringing off their brood.

Early in the present Session a "Bill to amend the IVild Birds' Protection Act, I 880," was brought into the House of Commons by Sir Herbert Maxwell, which Bill, owing to the well-deserved popularity of its introducer, ran its course unchallenged, and achieved the almost unexampled success of being read a third time and passed with scarcely an alteration of importance. The scope of the Bill was to enable any County Council to prohibit "the taking or destroying of any species of wild bird or the eggs of any species of wild bird." This Bill, of course, attracted the attention of the Committee which had been appointed the year before by the British Association " to consider proposals for the Legislative Protection of IVild Birds' Eggs," and in the opinion of that Committee, as subsequently reported at the late meeting of the Association at Nottingham, the Bill was declared to have been framed on a mistaken principle "in that it sought to effect the desired object by empowering local authorities to name the species, the eggs of which were to be protected, thus requiring in every case of prosecution proof of identity, which in the majority of cases would be difficult, if not impossible to supply."

The House of Lords at first took almost precisely the same view as the British Association Committee; and, chiefly at the instance of Lord Walsingham, than whom there could scarcely be a more competent peer, amended the Bill accordingly, producing what would, in the opinion of many experts, be a very workable measure. But unhappily in the subsequent process of passing the Standing Committee of the Upper House, their lordships were induced, by those who were not experts, to go a great deal further, and nobody acquainted with the facts of the questions involved, can doubt that on this occasion the efficacy of the Bill was not a little damaged in various ways. In this condition it in due course returned to the House of Commons, where the British Association Committee, as stated in their report, hoped it would, in spite of its transformation, still find favour; but its original parent, Sir Herbert Maxwell, would have none of it, and consideration of the Lords' Amendments having been adjourned on August 21 for three months, it stands by the accidental prolongation of the Session, for further discussion in a few days. In the meanwhile the British Association Committee has been reconstituted and strengthened by the substitution of several ornithologists of repute in place of some naturalists who had never paid any special attention to the matter, while Sir John Lubbock has accepted the post of chairman, and $\mathrm{Mr}$. Dresser, who was for many years Secretary to the Old "Close-Time" Committee of the Association that effected so much good, undertakes the same duty in the new body, the other members of which are Mr. Cordeaux, Mr. W. H. Hudson, Prof. Newton, Mr. Howard Saunders, Mr. T. H. Thomas, Canon Tristram, and Dr. Vachell. With a chairman at once so conciliatory and so influential, and a secretary of so much experience, it may be hoped that the difficulties, great as they are-for they involve a contest between the two Houses of Parliament -will not prove insuperable, and that some way may be found of saving this Bill, for all will admit that if it be not passed this Session a long while may elapse ere a House of Commons is good-humoured enough to let.a measure of the kind slip through its entanglements, as did that of Sir Herbert Maxwell at the beginning of this year. This is surely a case where sentiment should yield to common sense.

I It may be remarked that the Bill was so care:essly worded as to leave it open to duubt, though this was certainly not the intention of its supporters, whether a County Council could by one act make it apply to all Wi!d Birds, or only to some that should be named. 